\title{
How has dental pulp stem cells isolation been conducted? A scoping review
}

Camila Perelló FERRÚA(a) Eduarda Gervini Zampieri CENTENO(b) Laísa Camerini da ROSA(a) Cainá Corrêa do AMARAL(a) Rafaely Ferreira SEVERO(a) Rafael SARKIS-ONOFRE(c) Gustavo Giacomelli NASCIMENTO ${ }^{(d)}$ Gabriele CORDENONZI(a) Rachel Krolow BAST(e) Flávio Fernando DEMARCO(d) Fernanda NEDEL ${ }^{(a)}$

(a) Universidade Católica de Pelotas UCPel, Program in Health and Behavior, Pelotas, RS, Brazil.

(b) Universidade Federal de Pelotas - UFPel, Technology Development Center, Graduate Program in Biotecnology, Pelotas, RS, Brazil.

(c)|MED, Graduate Program in Dentistry, Passo Fundo, RS, Brazil.

(d) Universidade Federal de Pelotas UFPel, Graduate Program in Dentistry, Pelotas, RS, Brazil.

(e) Universidade Federal do Rio Grande do Sul UFRGS, Institute of Basic Health Scieces, Biochemistry Department, Porto Alegre, RS, Brazil.

Declaration of Interest: The authors certify that they have no commercial or associative interest that represents a conflict of interest in connection with the manuscript.

\section{Corresponding Author:}

Fernanda Nedel

E-mail: fernanda.nedel@gmail.com

https://doi.org/10.1590/1807-3107BOR-2017.vol31.0087

Submitted: May 14, 2017

Accepted for publication: Aug 8, 2017

Last revision: Sep 14, 2017
Abstract: The objective of this study was to realize a scoping review the literature in order to identify the profile of DPSCs isolation and analyze the possible risk factors that could change the native behavior of these cells. An initial search was conducted using the following MeSH terms: "(dental pulp stem cell [MeSH])"; “(dental pulp [MeSH])" AND "(stem cell $[\mathrm{MeSH}])$ "; "("dental pulp stem cell" [MeSH]")". The electronic search was done without date restriction up to and including April 2014, in PubMed, Scopus, Scielo and ISI Web of Knowledge databases. Studies were submitted to inclusion and exclusion criteria and 222 articles were included. Data showed that over the past 15 years many studies have been conducted using DPSCs. However this is the first systematic review regarding the isolation of stem cell, and more specifically of dental pulp stem cells. The isolation of dental pulp stem cells showed great variability, hampering the development of standard protocols to achieve in vitro dental pulp stem cells with similar characteristics. This scoping review combined, for the first time, the methodologies used for dental pulp stem isolation, highlighting the most frequently used.

Keywords: Dental Pulp; Stem Cells; Review.

\section{Introduction}

Currently, mesenchymal stem cells (MSCs) are commonly investigated for their contribution in the advance of fields such as cell therapy, tissue engineering and molecular biology, optimizing new treatment alternatives for common worldwide diseases. ${ }^{1}$ In 2000, Gronthos and collaborators identified MSCs in the pulp of permanent teeth, which were named dental pulp stem cells (DPSCs). ${ }^{2}$ This discovery provided an important source of stem cells, since DPSC s can be obtained by a minimally invasive process: ${ }^{3}$ from teeth extracted due to orthodontic reasons, periodontal disease or caries. ${ }^{4}$ Furthermore, DPSCs have shown high proliferative capacity, maintaining the potential of self-renewal and differentiation into multiple cell lineages. ${ }^{2}$

Several studies have considered DPSCs an appropriate cell model for various applications in different health-related fields. Since the knowledge about DPSCs is advancing rapidly towards the final goal of clinical application, some concerns, such as stem cell isolation, seem to be relegated to basic science background. Despite the use of DPSCs in the last 17 years and the cells' promising future, there is a gap in the literature concerning their isolation. Frequently, authors report inconsistent 
methodologies with missing information, thus the search for standardized protocols to achieve in vitro DPSCs isolation with consistent characteristics is hampered, possibly influencing the results of the evaluated outcomes. Thus, the aim of this study was to review the literature to identify the profile of DPSCs isolation and analyze the possible risk factors that could change the inherent behavior of these cells.

\section{Materials and Methods}

\section{Review study questions}

In the literature, how has the isolation of DPSCs been conducted?

Is there a published standardized protocol for DPSCs isolation?

\section{Inclusion and exclusion criteria}

The inclusion criteria for article assessment was presenting the methodology of stem cell isolation from dental pulp of human permanent teeth. Exclusion criteria are described in Figure 1.

\section{Search strategy}

The electronic search was conducted without initial date restriction up to and including April 2014 in PubMed, Scopus, Scielo and ISI Web of Knowledge databases. An initial search was conducted, without language restrictions, using the following MeSH terms: "(dental pulp stem cell [MeSH])"; "(dental pulp [MeSH])" AND "(stem cell [MeSH])"; "("dental pulp stem cell" [MeSH]")".

All references were managed in the EndNote X7 software (Thomson Reuters, New York, NY, US). Initially, duplicate references were excluded. Then, two reviewers (CPF and EGZC) independently screened titles, abstracts and study methodologies based on the inclusion and exclusion criteria. Selected studies were compared and in case of disagreement, a consensus was reached by discussion. When a consensus was not achieved, a third reviewer decided if the article should be included (FN). This systematic review followed the PRISMA statements ${ }^{5}$, with some adjustments (Figure 1).

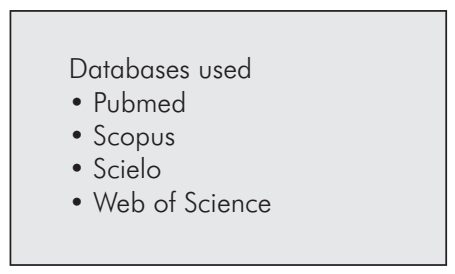

Records identified through databases searching $(n=3,126)$

Records remaining after $1 \mathrm{st}$ screening $(n=1,587)$
Duplicate records excluded ( $n=1,539)$
Studies excluded after full text reading

- No human cells $\left(n=240^{*}\right)$

- No pulp $(n=141)^{*}$

- Other issues $(n=139)^{*}$

- Isolation technique no described $\left(n=131^{*}\right)$

- Human pulp cells, but not stem $(n=118)^{*}$

- SHEDs $(n=96)^{*}$

- Language $(n=69)^{*}$

- Not found $(n=32)$

* Exclusion reasons (a study could have fulfilled more than one criterion)
Records excluded by titles and abstracts $(n=440)$

- Reviews ( $n=283$ )

- Congress summary $(n=50)$

- Patents $(n=50)$

- Book section $(n=24)$

- Hypothesis ( $n=13)$

- Editorial ( $n=9)$

- Letter to the editor $(n=6)$

- News $(n=2)$

- Protocol $(n=1)$

- Withdrawn $(n=1)$

- Interview $(n=1)$
Studies included in the systematic review $(n=222)$

Figure 1. Flow diagram of study selection. Risk of bias considering aspects reported in the material and method section. 


\section{Data extraction and quality assessment}

Data to be submitted to descriptive analysis were extracted and tabulated independently by two reviewers (CPF and LCdaR). Disagreements were discussed until a consensus was reached, and when a consensus was not obtained, a third reviewer was consulted (FN).

\section{Risk of bias in included studies}

Studies risk of bias was evaluated according to the presence (yes, Y) or absence (no, N) of description of the parameters presented in Figure 2. It was established that up to $30 \%$ of Ys represented high risk of bias, from 31 to $65 \%$ represented medium risk, and above $65 \%$ was low risk of bias.

\section{Results}

\section{Descriptive analysis}

The electronic search provided 3,126 articles. From those, 1,539 were duplicated and therefore, removed. A total of 1,587 articles were included for title, abstract and methodology screening. From those, 222 were included for full text analysis (Figure 1).

Of the included studies, $100 \%$ described the enzyme type. The second item most frequently mentioned by the authors was the medium used for DPSCs in vitro culture. However, the size of fragments in the explant technique, and cell filtration in the enzymatic and/or mechanical technique were the most neglected items (Table 1).
The three main techniques described in the literature to isolate DPSCs are explant, enzymatic and mechanical, or in some cases the association between the latter two methodologies. Among the selected articles for this systematic review, 56.3\% conducted the enzymatic technique ${ }^{6}$ followed by $33.5 \%$ that applied an association between the enzymatic and mechanical techniques ${ }^{7}$. The less frequent isolation techniques were the explant, ${ }^{8,9} 9.8 \%$, and the mechanical methodology, ${ }_{10}^{10} 0.5 \%$.

Twenty different combinations of enzymes were used in the enzymatic technique for DPSCs isolation. Collagenase type I associated with dispase was the most frequently used, ${ }^{11,12}$ in second place was collagenase type I alone. ${ }^{13}$ Ten different enzyme combinations were used in less than $5 \%$ of the selected articles (Table 2).

Table 1. Distribution according to the presence or absence of important aspects of DPSCs isolation.

\begin{tabular}{lcccc}
\hline \multirow{2}{*}{ Variable } & \multicolumn{3}{c}{ Yes } & \multicolumn{2}{c}{ No } \\
\cline { 2 - 5 } & $\mathrm{n}$ & $\%$ & $\mathrm{n}$ & $\%$ \\
\hline Size of explant fragments & 12 & 54.5 & 10 & 45.5 \\
Enzyme type & 200 & 100 & 0 & 0 \\
\hline Enzyme concentration (enzymatic technique) & 116 & 90.6 & 12 & 9.4 \\
\hline Enzyme concentration (association technique) & 67 & 89.3 & 8 & 10.7 \\
\hline Culture medium & 212 & 95 & 10 & 5.0 \\
Cell filtration & 106 & 47.75 & 116 & 52.25 \\
\hline Serum & 195 & 87.8 & 27 & 12.2 \\
Supplementation (serum excluded) & 179 & 90. & 20 & 10 \\
\hline
\end{tabular}

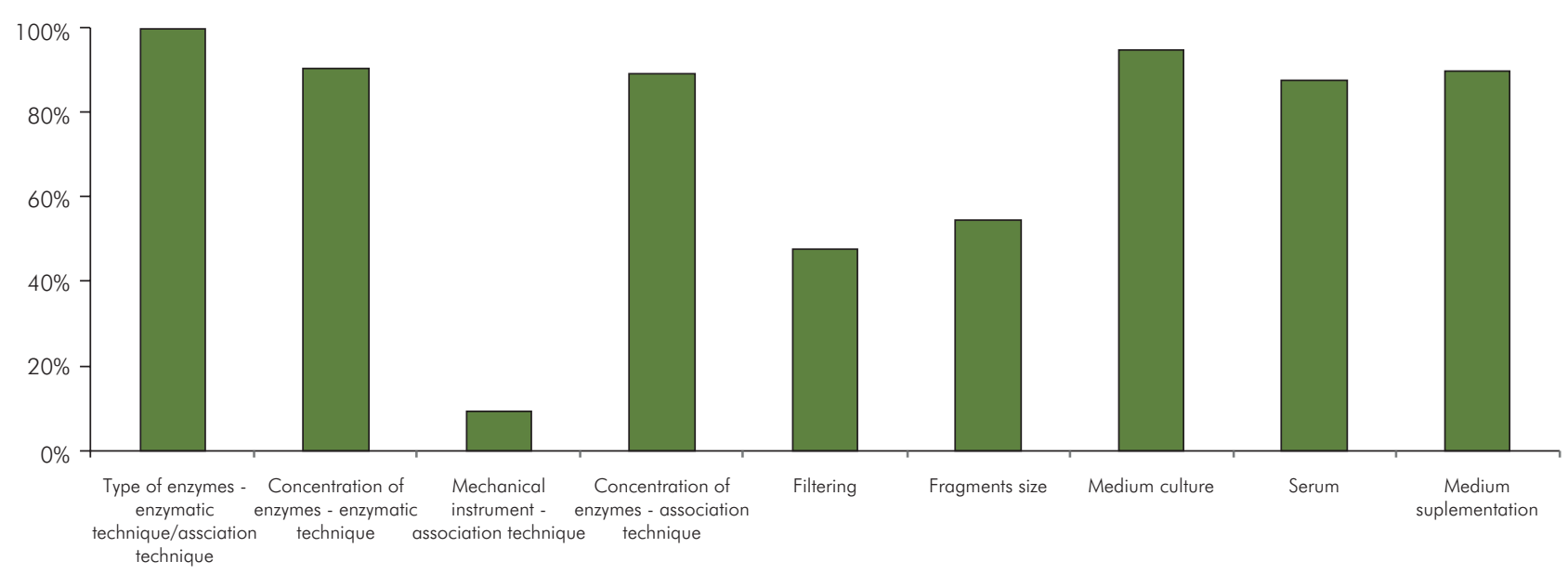

Figure 2. Risk of bias considering aspects reported in the material and method section. 
Table 2. Distribution according to the type of enzymes used for DPSCs isolation with the enzymatic technique or in the association of the enzymatic and mechanical techniques.

\begin{tabular}{lcc}
\hline Variable & $\mathrm{n}$ & $\%$ \\
\hline Collagenase type I and dispase* & 111 & 54.4 \\
\hline Collagenase type I & 35 & 17.2 \\
\hline Collagenase and dispase* & 14 & 6.9 \\
\hline Collagenase* & 9 & 4.4 \\
\hline Collagenase type I and dispase type II & 8 & 3.9 \\
\hline Trypsin & 5 & 2.5 \\
\hline Collagenase type I and collagenase type II & 4 & 2.0 \\
\hline Collagenase type IA & 2 & 1.0 \\
\hline Collagenase type II & 2 & 1.0 \\
\hline Dispase type I & 1 & 1.0 \\
\hline Collagenase type A & 1 & 1.0 \\
\hline Collagenase type IA and dispase* & 1 & 1.0 \\
\hline Collagenase type II and dispase type I & 1 & 1.0 \\
\hline Collagenase and dispase type II* & 1 & 1.0 \\
\hline Collagenase/DNAse & 1 & 1.0 \\
\hline Collagenase type I and DNAse & 3 & 1.5 \\
\hline Trypsin and collagenase & 1 & 1.0 \\
\hline Collagenase Blend type H & 100.00 \\
\hline Collagenase type I, colLagenase type II, & 1 & 1.0 \\
\hline termolisina & 1 & 1.0 \\
\hline Total described types of enzymes used & 1.0 \\
\hline The type of collagenase and/or dispase was not & Iescibed \\
\hline
\end{tabular}

*The type of collagenase and/or dispase was not described.

An important variable in the explant technique is the size of tissue fragments. Although studies reported up to five different sizes, all mentioned sectioning the tissue into small pieces. About $18 \%$ did not state the precise dimension and $45.5 \%$ did not mention the size of the fragments.

In the mechanical technique, either alone or in combination with the enzymatic technique, a filtration step is usually performed. Of the included studies, $69.8 \%$ used a $70 \mu \mathrm{m}$ filter, $10.4 \%$ used a $100 \mu \mathrm{m}$ filter and $10.4 \%$ used a $40 \mu \mathrm{m}$ filter. Furthermore, $9.4 \%$ of the studies that mentioned filtration did not described the filter pore size.

Ninety-five percent of the studies described 19 different mediums used for DPSCs in vitro culture (Table 1). The most commonly used was $\alpha-M_{E M}{ }^{14,15}$ followed by DMEM ${ }^{16,17}$ (Table 3).
Table 3. Distribution according to the types of medium used for culturing DPSCs.

\begin{tabular}{|c|c|c|}
\hline Variable & $\mathrm{n}$ & $\%$ \\
\hline$\alpha$-MEM & 114 & 52.3 \\
\hline DMEM & 46 & 21,10 \\
\hline DMEM/F12 & 9 & 4.1 \\
\hline DMEM-KO & 7 & 3.2 \\
\hline Low glucose DMEM & 7 & 3.2 \\
\hline MEM & 7 & 3.2 \\
\hline MSCM & 5 & 2.3 \\
\hline Mega Cell & 5 & 2.3 \\
\hline$M C M$ & 3 & 1.4 \\
\hline A-DMEM & 2 & 0.9 \\
\hline DMEM/Ham'sF12 & 2 & 0.9 \\
\hline EBM2 & 2 & 0.9 \\
\hline MCDB-201 & 2 & 0.9 \\
\hline MEM-Earle & 2 & 0.9 \\
\hline BME & 1 & 0.5 \\
\hline High-glucose DMEM & 1 & 0.5 \\
\hline Low glucose DMEM and MCDB-201 & 1 & 0.5 \\
\hline $\mathrm{NH}$ stem cell expansion & 1 & 0.5 \\
\hline Phenol red free L-DMEM & 1 & 0.5 \\
\hline Total & 218 & 100.0 \\
\hline \multicolumn{3}{|c|}{$\begin{array}{l}\alpha \text {-MEM: } \alpha \text {-minimum essential medium; DMEM: Dulbecco's } \\
\text { modified Eagle's medium; DMEM/F12: Dulbecco's modified Eagle's } \\
\text { medium/F12; DMEM-KO: Dulbecco's modified Eagle's medium - } \\
\text { knock-out; MEM: minimum essential medium; MSCM: mesenchymal } \\
\text { stem cell medium; MCM: mesencult complete médium; A-DMEM: } \\
\text { advanced Dulbecco's modified Eagle'S medium; DMEM/ } \\
\text { Ham'sF12: Dulbecco's modified Eagle's medium/Ham's F12; EBM2: } \\
\text { endothelial cell basal medium 2; MEM-Earle: minimum essential } \\
\text { medium-earle; BME: basal medium eagle; NH stem cell expansion: } \\
\text { nonhematopoietic stem cell expansion. }\end{array}$} \\
\hline
\end{tabular}

The in vitro supplementation of DPSCs is also an important issue. Of the studies included, 90\% mentioned the use of supplementation, other than serum (Table 1). The most commonly used serum was fetal bovine serum (FBS), followed by fetal calf serum (FCS), human serum and FCS in association with FBS. The vast majority of studies supplemented the culture medium with two, three or four components, other than serum. The most cited ones were penicillin and streptomycin, accounting for more than $50 \%$ of all compounds used for supplementation (Table 4). 
Table 4. Distribution according to the supplementation used in DPSCs culture medium preparation (some studies used more than one culture medium).

\begin{tabular}{|c|c|c|}
\hline Variable & $n$ & $\%$ \\
\hline Penicilin & 157 & 26.0 \\
\hline Streptomicin & 151 & 25.0 \\
\hline L -glutamine & 61 & 10.1 \\
\hline L-ascorbic acid & 40 & 6.6 \\
\hline 2P-ascorbic acid & 28 & 4.5 \\
\hline Glutamine & 18 & 3.0 \\
\hline Amphotericin & 16 & 2.6 \\
\hline AA & 14 & 2.3 \\
\hline Dexamethasone & 13 & 2.1 \\
\hline Fungizone & 12 & 2.0 \\
\hline Gentamicin & 11 & 1.8 \\
\hline PDGF & 9 & 1.5 \\
\hline Glutamax & 9 & 1.5 \\
\hline EGF & 9 & 1.5 \\
\hline Antibiotics & 7 & 1.2 \\
\hline Insulin & 7 & 1.2 \\
\hline Selenium & 7 & 1.2 \\
\hline Transferrin & 7 & 1.2 \\
\hline hPDGF BB & 3 & 0.5 \\
\hline LA-BSA & 3 & 0.5 \\
\hline Glucose & 3 & 0.5 \\
\hline$\beta F G F$ & 2 & 0.3 \\
\hline BSA & 2 & 0.3 \\
\hline hLIF & 2 & 0.3 \\
\hline Clarithromycin & 2 & 0.3 \\
\hline CDLC & 2 & 0.3 \\
\hline Kanamycin & 2 & 0.3 \\
\hline Vitamin C & 2 & 0.3 \\
\hline IGF & 1 & 0.2 \\
\hline$B-M E$ & 1 & 0.2 \\
\hline Ciprofloxacin & 1 & 0.2 \\
\hline Sodium pyruvate & 1 & 0.2 \\
\hline Hepes & 1 & 0.2 \\
\hline Mesenchymal cell growth supplement & 1 & 0.2 \\
\hline Total & 605 & 100.0 \\
\hline
\end{tabular}

AA: antibiotic antimycotic solution; PDGF: platelet-derived growth factor; EGF: epidermal growth factor; hPDGF BB: human recombinant platelet-derived growth factor; LA-BSA: linoleic acidbovine serum albumin; bFGF: basic fibroblast growth factor; BSA: bovine serum albumin; hLIF: human leukemia inhibitor factor; CDLC: chemically defined lipid concentrate; IGF: insulin-like growth factor; B-ME: B-mercaptoethanol.

\section{Risk of Bias}

Of the 222 studies included in this review, only $9.3 \%$ described the instrument used for the mechanical dissociation in the combined technique, representing a high risk of bias. Information about the filtration process and fragment size of the explant was mentioned respectively in 47.8 and $54.6 \%$ of all studies; both items showed medium risk of bias. All studies described the type of enzyme used, indicating a low risk of bias for this variable. The enzyme concentration was described in 89.3 and $90.6 \%$ of the studies applying the combined methodology and the enzymatic techniques, respectively. The culture medium (95.1\%), serum (87.8\%) and the medium supplementation $(90.0 \%)$ were considered as low risk of bias (Figure 2).

\section{Discussion}

Over the past 17 years, many studies have been conducted using DPSCs. However, there is still a gap in the literature concerning a standardized protocol for DPSC isolation. This is the first time that the vast literature regarding DPSCs isolation methodology has been summarized in a rigorous and replicable manner (Figure 3).

It is important to highlight that the data presented in this article are based on frequency analysis of various factors of the DPSCs isolation. One can argue that a better evaluation would be done by looking at the outcomes of the articles, rather than the frequency of the isolation techniques used. However, it is well known that negative results are not always published, which could lead to seriously biased results. In addition, few studies included in this scoping review were strictly methodological, with the purpose of evaluating DPSCs isolation. Most of them performed cell isolation and culture for secondary purposes. Therefore, if DPSCs isolation was described in the methodology section of studies and secondary evaluations were conducted, we can accept that the isolation process succeeded. In this scenario, the frequency of variables would be the most accurate data to be evaluated.

The DPSCs isolation process has evolved overtime and currently it can be done using two main techniques: explant ${ }^{18,19,20}$ and enzymatic, ${ }^{19,20}$ the 


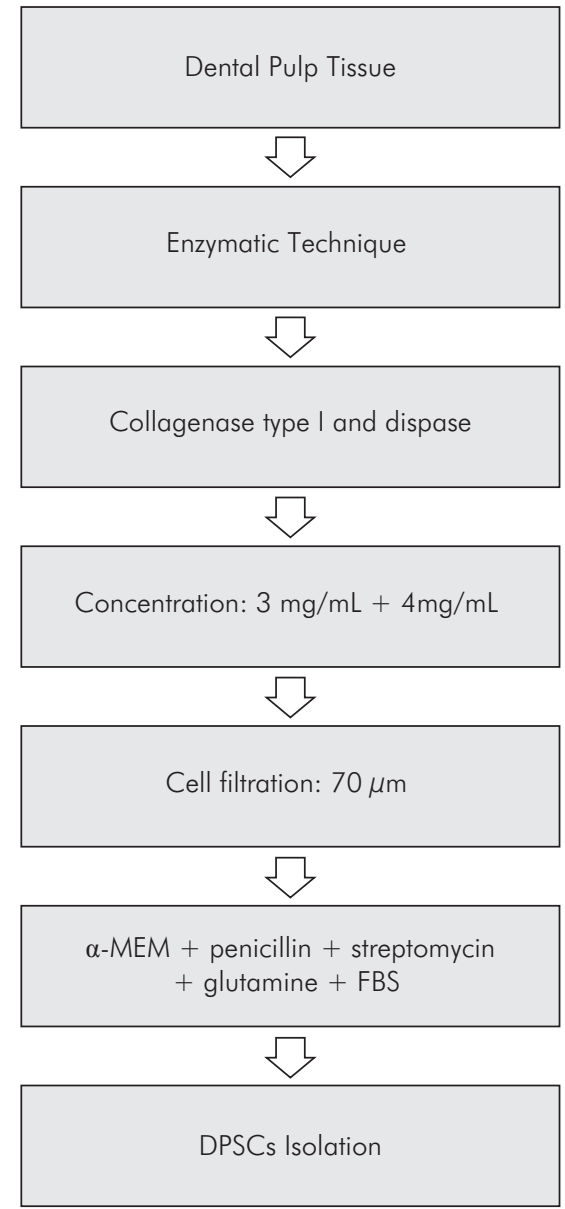

Figure 3. Flowchart summarizing the principal results obtained from this systematic review, highlighting the most commonly used steps for DPSCs isolation.

association between the enzymatic technique and the use of mechanical devices to intensify cell dissociation has also been used. ${ }^{21}$

Our findings revealed that $56.3 \%$ of the included studies applied the enzymatic technique, and 33.5\% associated this methodology with the mechanical cell dissociation step. The enzymatic technique consists of removing DPSCs from dental pulp by using enzymes, such as collagenase, dispase ${ }^{19}$ and trypsin, ${ }^{22}$ to dissociate cells from each other and from its extracellular matrix, and obtain a heterogeneous singularized cell suspension. However, this process can cause cell damage and induce cell death if not done properly. ${ }^{23}$

All evaluated articles in our study described the enzyme used for DPSCs dissociation. Only five families of enzymes were mentioned: collagenase, dispase, trypsin, thermolysin and DNAase. Twenty different enzyme combinations were described; the most frequently mentioned was collagenase type I/dispase, and the second was collagenase type I alone. Some studies did not specify the enzyme subtype, informing only the family of the enzyme. Since the dental pulp is a connective tissue and its extracellular matrix contains collagen as a major component, ${ }^{24}$ the common use of collagenase and dispase, two proteolytic enzymes that degrade collagen, is highly justified..$^{25,26}$

In addition, the concentrations of the enzymes in the most commonly used combination (collagenase type I/dispase) were not standardized within studies, with up to eight different values. This high variability in concentrations was also observed for collagenase, collagenase type I and collagenase/dispase. This lack of standardization of the type of enzyme and its concentration could compromise DPSCs survival and function, and therefore hamper stem cell isolation.

After enzymatic disaggregation, the tissue suspension is commonly filtered through a Falcon cell strainer. ${ }^{27}$ This process is done to remove any cell clump, ${ }^{28}$ and the filter pore size can be selected according to cell type. Our data showed that studies used filters with pore size of 40, 70 and $100 \mu \mathrm{m}$.

Similar to the enzymatic methodology, the explant technique is able to isolate cells that can differentiate into multiple lineages. ${ }^{29}$ This technique is based on the outgrowth of cells from small tissue fragments, and it allows the isolation of a relatively pure population of pulp stem cells. ${ }^{19}$ However, a heterogeneous population of cells, achieved with the enzymatic technique, is needed in some cell-based therapy approaches, since it can endure various environmental signals within the tissue ${ }^{29}$.

The explant methodology is more cost-effective than the enzymatic technique. ${ }^{30}$ However, only $9.9 \%$ of the authors used this technique. This might be related to the long time needed to conduct this method, since cells need from 1 to 2 weeks to migrate from the pulp tissue. Lizier and collaborators developed a cell culture method that preserves DPSCs viability for longer periods, minimizing the slow proliferation rate. ${ }^{18}$ The methodology is based on the explant technique, and it consists in transferring tissue fragments to a different plate every time the desired cell density is achieved. 
It allows the de novo cell migration to a new plate, enabling the achievement of larger amounts of pulp stem cells. ${ }^{18}$

Few studies have compared the enzymatic and explant techniques for DPSCs isolation. ${ }^{23,29,31}$ In a well-designed study, Hilkens and collaborators showed that cells isolated by the enzymatic or the explant techniques had the same proliferating rate and colony formation capacity, and could successfully differentiate into adipogenic, chrondrogenic and osteogenic cell types, indicating that both isolation methodologies could be applied to obtain suitable autologous DPSCs. ${ }^{29}$

One particular aspect of the explant technique is the size of tissue fragments. According to our results fragment dimensions are not standardized, since $45.5 \%$ of the articles did not provide this information and $18.2 \%$ only mentioned that tissue fragments were small. The relevance of the explant size in the successful isolation of DPSCs has been poorly explored in the literature. Verdugo et al. ${ }^{32}$ compared two sizes of explants from bone tissue, and observed that the size of explants did not influence osteoblast outgrowth. Nevertheless, this finding should be considered with caution, since cells from different sources can behave differently. In general, the explant should not be excessively small as it can compromise its attachment to the bottom of the culture plate, affecting cell outgrowth. On the other hand, if the explant is too large it can compromise the diffusion of metabolites and nutrients between the culture medium and the explant.

Another aspect is determining the adequate culture medium and its supplements, which will enable the in vitro culture of the isolated cells. ${ }^{33}$ Our data showed that nearly $95 \%$ of the articles described the culture medium used for DPSCs (Table 1), indicating a very low risk of bias and therefore highlighting the relevance of this factor. Nineteen different types of culture medium were cited. Of these, $\alpha$-MEM, DMEM and DMEM/F12 were the most used (Table 3). It is therefore observed that the literature is limited concerning the ideal medium for DPSCs isolation.

Ninety percent of the articles included information concerning cell culture medium supplementation. Specifically in relation to serum, $87.8 \%$ of the articles cited its use, with FBS and FCS being the most recommended ones. This is probably due to the widespread use of FBS in published studies on
DPSCs culture. ${ }^{2,34}$ However, serum from animal source can present disadvantages such as risks of infections and immunological reactions. Indeed, mesenchymal stem cells have been reported to express $\mathrm{N}$-glycolylneuraminic acid (Neu5Gc) xenoantigen that humans are unable to synthesize, indicating that cells uptake them from the culture media components. The human serum contains natural antibodies against Neu5Gc xenoantigen and their binding could lead to an immune response by antibody-dependent cell-mediated cytotoxicity mechanisms. In addition, the monocyte-derived macrophages could increase phagocytosis of mesenchymal stem cells cultured in animal serum. These processes could influence the survival and efficacy of the transplanted cells in clinical applications. ${ }^{35,36}$ Thus, alternative supplements have been investigated. Serum-free media have been continuously tested for stem cell culture; however, so far, the literature indicates that these media do not adequately support DPSCs proliferation and differentiation. ${ }^{37,38}$ The growth of DPSCs with a small percentage of serum enriched with epidermal growth factor (EGF) and platelet-derived growth factor (PDGF) could represent a valid perspective. ${ }^{39,40}$ Various human blood derivatives have been proposed as alternatives to animal serum for stem cell culture. These include autologous or allogenic human serum, ${ }^{38}$ human plasma, ${ }^{37}$ and human platelet lysates and their released factors. ${ }^{4}$ Pisciolaro and collaborators showed that autologous human serum induces higher CFUs capacity, higher degree of mineralization and less cell damage in DPSCs cells then FBS and allogenic human serum. ${ }^{38}$ Pisciotta and collaborators showed that human serum is an appropriate alternative for FCS, enhancing DPSC proliferation rate and improving in vitro differentiation, and when implanted in immunocompromised rats these cells can restore critical size bone defects. ${ }^{37}$ Chen and collaborators showed that when $5 \%$ of human platelet lysate was incorporated in normal culture medium the proliferation and mineralization rates were enhanced. ${ }^{4}$ Although the literature refers to human platelets as a substitute for FBS, some articles used them in association with FBS, more likely as supplement.

The risk of bias analysis of several variables of interest allowed us to estimate the quality of the 
included studies. In general, we found that studies showed low risk of bias for most variables of interest.

In conclusion, over the years, many studies have been conducted using DPSCs. However, this is the first scoping review regarding the isolation of DPSCs. The methodology for DPSCsisolation showed great variability,

\section{References}

1. Uccelli A, Moretta L, Pistoia V. Mesenchymal stem cells in health and disease. Nat Rev Immunol. 2008;8(9):726-36. https://doi.org/10.1038/nri2395

2. Gronthos S, Mankani M, Brahim J, Robey PG, Shi S. Postnatal human dental pulp stem cells (DPSCs) in vitro and in vivo. Proc Natl Acad Sci USA. 2000;97(25):13625-30. https://doi.org/10.1073/pnas.240309797

3. Liu J, Yu F, Sun Y, Jiang B, Zhang W, Yang J et al. Concise reviews: characteristics and potential applications of human dental tissue-derived mesenchymal stem cells. Stem Cells. 2015;33(3):627-38. https://doi.org/10.1002/stem.1909

4. Chen B, Sun HH, Wang HG, Kong H, Chen FM, Yu Q. The effects of human platelet lysate on dental pulp stem cells derived from impacted human third molars. Biomaterials. 2012;33(20):5023-35. https://doi.org/10.1016/i.biomaterials.2012.03.057

5. Moher D, Liberati A, Tetzlaff J, Altman DG. Preferred reporting items for systematic reviews and meta-analyses: the PRISMA statement. BMJ. 2009;339 jul21 1:b2535. https://doi.org/10.1136/bmi.b2535

6. Arthur A, Rychkov G, Shi S, Koblar SA, Gronthos S. Adult human dental pulp stem cells differentiate toward functionally active neurons under appropriate environmental cues. Stem Cells. 2008;26(7):1787-95. https://doi.org/10.1634/stemcells.2007-0979

7. Agha-Hosseini F, Jahani MA, Jahani M, Mirzaii-Dizgah I, Ali-Moghaddam K. In vitro isolation of stem cells derived from human dental pulp. Clin Transplant. 2010;24(2):E23-8. https://doi.org/10.1111/j.1399-0012.2009.01137.x

8. Diomede F, Caputi S, Merciaro I, Frisone S, D'Arcangelo C, Piattelli $A$ et al. Pro-inflammatory cytokine release and cell growth inhibition in primary human oral cells after exposure to endodontic sealer. Int Endod J. 2014;47(9):864-72. https://doi.org/10.1111/iej.12230

9. Nesti C, Pardini C, Barachini S, D'Alessandro D, Siciliano G, Murri $L$ et al. Human dental pulp stem cells protect mouse dopaminergic neurons against MPP+ or rotenone. Brain Res. 2011;1367:94-102. https://doi.org/10.1016/i.brainres.2010.09.042

10. Aquino R, De Rosa A, Lanza V, Tirino V, Laino L, Graziano A et al. Human mandible bone defect repair by the grafting of dental pulp stem/progenitor cells and collagen sponge biocomplexes. Eur Cell Mater. 2009;18:75-83. https://doi.org/10.22203/eCM.v018a07 hampering the development of standard protocols to obtain DPSCs in vitro with similar characteristics of those in vivo, and possibly influencing the results of the evaluated outcomes. This study, therefore, reviews the methodologies used for dental pulp stem cell isolation, highlighting the most frequently used.
11. Gay I, Cavender A, Peto D, Sun Z, Speer A, Cao H et al. Differentiation of human dental stem cells reveals a role for microRNA-218. J Periodontal Res. 2014;49(1):110-20. https://doi.org/10.1111/ire.12086

12. Niu LN, Sun JQ, Li QH, Jiao K, Shen LJ, Wu D et al. Intrafibrillarsilicified collagen scaffolds enhance the osteogenic capacity of human dental pulp stem cells. J Dent. 2014;42(7):839-49. https://doi.org/10.1016/j.jdent.2014.03.016

13. Govindasamy V, Ronald VS, Abdullah AN, Nathan KR, Ab Aziz ZA, Abdullah M et al. Differentiation of dental pulp stem cells into islet-like aggregates. J Dent Res. 2011;90(5):646-52. https://doi.org/10.1177/0022034510396879

14. Graziano A, Aquino R, Laino G, Proto A, Giuliano MT, Pirozzi $G$ et al. Human CD34+ stem cells produce bone nodules in vivo. Cell Prolif. 2008;41(1):1-11. https://doi.org/10.1111/j.1365-2184.2007.00497.x

15. Luo Z, Kohli MR, Yu Q, Kim S, Qu T, He WX. Biodentine induces human dental pulp stem cell differentiation through mitogen-activated protein kinase and calcium-/ calmodulin-dependent protein kinase II pathways. J Endod. 2014;40(7):937-42. https://doi.org/10.1016/i.joen.2013.11.022

16. Lindroos B, Mäenpää K, Ylikomi T, Oja H, Suuronen R, Miettinen S. Characterisation of human dental stem cells and buccal mucosa fibroblasts. Biochem Biophys Res Commun. 2008 Apr;368(2):329-35. https://doi.org/10.1016/i.bbrc.2008.01.081

17. Marchionni C, Bonsi L, Alviano F, Lanzoni G, Di Tullio A, Costa R et al. Angiogenic potential of human dental pulp stromal (stem) cells. Int J Immunopathol Pharmacol. 2009;22(3):699-706. https://doi.org/10.1177/039463200902200315

18. Lizier NF, Kerkis A, Gomes CM, Hebling J, Oliveira CF, Caplan Al et al. Scaling-up of dental pulp stem cells isolated from multiple niches. PLoS One. 2012;7(6):e39885. https://doi.org/10.1371/journal.pone.0039885

19. Kerkis I, Kerkis A, Dozortsev D, Stukart-Parsons GC, Gomes Massironi SM, Pereira LV et al. Isolation and characterization of a population of immature dental pulp stem cells expressing OCT-4 and other embryonic stem cell markers. Cells Tissues Organs. 2006;184(3-4):105-16. https://doi.org/10.1159/000099617 
Ferrúa, Centeno, Rosa, Amaral, Severo, Sarkis-Onofre et al.

20. Karamzadeh R, Eslaminejad MB, Aflatoonian R. Isolation, characterization and comparative differentiation of human dental pulp stem cells derived from permanent teeth by using two different methods. J Vis Exp. 2012;(69):pii. 4372. https://doi.org/10.3791/4372

21. Patil R, Kumar BM, Lee WJ, Jeon RH, Jang SJ, Lee $Y M$ et al. Multilineage potential and proteomic profiling of human dental stem cells derived from a single donor. Exp Cell Res. 2014;320(1):92-107. https://doi.org/10.1016/i.yexcr.2013.10.005.

22. Asgary S, Nazarian H, Khojasteh A, Shokouhinejad N. Gene expression and cytokine release during odontogenic differentiation of human dental pulp stem cells induced by 2 endodontic biomaterials. J Endod. 2014;40(3):387-92. https://doi.org/10.1016/i.joen.2013.09.017

23. Huang GT, Sonoyama W, Chen J, Park SH. In vitro characterization of human dental pulp cells: various isolation methods and culturing environments. Cell Tissue Res. 2006;324(2):225-36. https://doi.org/10.1007/s00441-005-0117-9

24. Lukinmaa PL, Waltimo J. Immunohistochemical localization of types I, V, and $\mathrm{VI}$ collagen in human permanent teeth and periodontal ligament. J Dent Res. 1992;71(2):391-7. https://doi.org/10.1177/00220345920710020801

25. Koga H, Muneta T, Nagase T, Nimura A, Ju YJ, Mochizuki T et al. Comparison of mesenchymal tissues-derived stem cells for in vivo chondrogenesis: suitable conditions for cell therapy of cartilage defects in rabbit. Cell Tissue Res. 2008;333(2):207-15. https://doi.org/10.1007/s00441-008-0633-5

26. Rodbell M. Metabolism of isolated fat cells. I. Effects of hormones on glucose metabolism and lipolysis. J Biol Chem. 1964;239:375-80.

27. Pisciotta A, Carnevale G, Meloni S, Riccio M, De Biasi S, Gibellini L et al. Human dental pulp stem cells (hDPSCs): isolation, enrichment and comparative differentiation of two sub-populations. BMC Dev Biol. 2015;15(1):14. https://doi.org/10.1186/s12861-015-0065-x

28. Francis MP, Sachs PC, Elmore LW, Holt SE. Isolating adipose-derived mesenchymal stem cells from lipoaspirate blood and saline fraction. Organogenesis. 2010;6(1):11-4. https://doi.org/10.4161/org.6.1.10019

29. Hilkens P, Gervois P, Fanton Y, Vanormelingen J, Martens W, Struys $T$ et al. Effect of isolation methodology on stem cell properties and multilineage differentiation potential of human dental pulp stem cells. Cell Tissue Res. 2013;353(1):65-78. https://doi.org/10.1007/s00441-013-1630-x

30. Huang GT, Shagramanova K, Chan SW. Formation of odontoblast-like cells from cultured human dental pulp cells on dentin in vitro. J Endod. 2006;32(11):1066-73. https://doi.org/10.1016/i.joen.2006.05.009
31. Spath L, Rotilio V, Alessandrini M, Gambara G, De Angelis L, Mancini $M$ et al. Explant-derived human dental pulp stem cells enhance differentiation and proliferation potentials. J Cell Mol Med. 2010;14(6B):1635-44. https://doi.org/10.1111/j.1582-4934.2009.00848.x

32. Verdugo F, Sáez-Rosón A, Uribarri A, Martínez-Conde R, Cabezas-Olcoz J, Moragues MD et al. Bone microbial decontamination agents in osseous grafting: an in vitro study with fresh human explants. J Periodontol. 2011;82(6):863-71. https://doi.org/10.1902/jop.2010.100514

33. Pal R, Hanwate M, Jan M, Totey S. Phenotypic and functional comparison of optimum culture conditions for upscaling of bone marrow-derived mesenchymal stem cells. J Tissue Eng Regen Med. 2009;3(3):163-74. https://doi.org/10.1002/term.143

34. Abdullah MF, Abdullah SF, Omar NS, Mahmood Z, Fazliah Mohd Noor SN, Kannan TP et al. Proliferation rate of stem cells derived from human dental pulp and identification of differentially expressed genes. Cell Biol Int. 2014;38(5):582-90. https://doi.org/10.1002/cbin.10229

35. Heiskanen A, Satomaa T, Tiitinen S, Laitinen A, Mannelin S, Impola $\mathrm{U}$ et al. $\mathrm{N}$-glycolylneuraminic acid xenoantigen contamination of human embryonic and mesenchymal stem cells is substantially reversible. Stem Cells. 2007;25(1):197202. https://doi.org/10.1634/stemcells.2006-0444

36. Komoda H, Okura H, Lee CM, Sougawa N, Iwayama T, Hashikawa T et al. Reduction of N-glycolylneuraminic acid xenoantigen on human adipose tissue-derived stromal cells/ mesenchymal stem cells leads to safer and more useful cell sources for various stem cell therapies. Tissue Eng Part A.

2010;16(4):1143-55. https://doi.org/10.1089/ten.tea.2009.0386

37. Pisciotta A, Riccio M, Carnevale G, Beretti F, Gibellini L, Maraldi T et al. Human serum promotes osteogenic differentiation of human dental pulp stem cells in vitro and in vivo. PLoS One. 2012;7(11):e50542. https://doi.org/10.1371/journal.pone.0050542

38. Pisciolaro RL, Duailibi MT, Novo NF, Juliano Y, Pallos D, Yelick PC et al. Tooth Tissue Engineering: The Importance of Blood Products as a Supplement in Tissue Culture Medium for Human Pulp Dental Stem Cells. Tissue Eng Part A. 2015;21(21 22):2639-48. https://doi.org/10.1089/ten.tea.2014.0617

39. Ferro F, Spelat R, Beltrami AP, Cesselli D, Curcio F. Isolation and characterization of human dental pulp derived stem cells by using media containing low human serum percentage as clinical grade substitutes for bovine serum. PLoS One. 2012;7(11):e48945. https://doi.org/10.1371/journal.pone.0048945

40. Karbanová J, Soukup T, Suchánek J, Pytlík R, Corbeil D, Mokrý J. Characterization of dental pulp stem cells from impacted third molars cultured in low serum-containing medium. Cells Tissues Organs. 2011;193(6):344-65. https://doi.org/10.1159/000321160 